\title{
Balzac: An Artist and an Entrepreneur
}

\author{
Lorenzo Gelmini ${ }^{1}$ \\ ${ }^{1}$ University of Eastern Piedmont, Italy \\ Correspondence: Lorenzo Gelmini, University of Eastern Piedmont, Italy.
}

Received: August 22, 2018

Accepted: September 14, 2018

Online Published: January 14, 2019

doi:10.20849/ajsss.v4i1.538

URL: https://doi.org/10.20849/ajsss.v4i1.538

\begin{abstract}
Balzac has been widely regarded as one of the greatest storytellers of humanity; his ability to describe an entire universe of characters makes his work a real living system, truly devoted to an ambitious project. At the same time his sparkling and puzzled existence is itself a novel.

As such, analyzing some key moments in Balzac's life, from a specific financial standpoint and business perspective, allows us to better understand the genesis of his work: and vice versa.

In effect, the main research question of this paper is to identify some key moments in Balzac's life that have affected him from a financial perspective and that have drawn him to a mature and profound knowledge of the social and economic mechanisms, essential for writing his great masterpieces.

At the same time, and on the contrary direction, attention will be devoted to some of his novels that have a clear economic and financial plot: as above, they certainly have emerged from the knowledge of the social life in France in the nineteenth century via his daily vicissitudes.
\end{abstract}

Keywords: accounting, arts, entrepreneurship

\section{Introduction and Motivations of the Paper}

Balzac has been widely regarded as one of the greatest storytellers of humanity; his ability to describe an entire universe of characters makes his work a real living system, truly devoted to an ambitious project. At the same time his sparkling and puzzled existence is itself a novel.

As such, analyzing some key moments in Balzac's life, from a specific financial standpoint and business perspective, allows us to better understand the genesis of his work: and vice versa.

In effect, the main research question of this paper is to identify some key moments in Balzac's life that have affected him from a financial perspective and that have drawn him to a mature and profound knowledge of the social and economic mechanisms, essential for writing his great masterpieces.

At the same time, and on the contrary direction, attention will be devoted to some of his novels that have a clear economic and financial plot: as above, they certainly have emerged from the knowledge of the social life in France in the nineteenth century via his daily vicissitudes.

The mutual and intertwined relationship, in Balzac, between life, money, enterprises and novels, was already captured by Zola (1923), who states that "it is not only for his daily bread that Balzac asks of his books; he asks them to make up for the losses he incurs in industry".

Money and power are the central protagonists of "La Comédie Humaine", which is populated by aristocrats, adventurers, lawyers, careerists, speculators, bankers, financiers and usurers. Balzac is in fact, within the greatest authors, the one who has best grasped the relationship between economic and social factors, thus making himself an ideal object for the field of study of Business Economics.

It is no coincidence that Thomas Piketty's celebrated work on capital overwhelms predominately quantitative analysis of economic inequality and it begins, on the contrary, with the novels of Balzac. In effect, according to Pace-Siegge (2018) "there are around three times as many references to the litterateur Honoré de Balzac in Piketty's s book as there are to Karl Marx".

Given the systemic nature of his work, this paper embraces pieces of the entire "La Comédie Humaine". 


\section{Structure of the Paper}

The structure of the paper is as follows:

1) analysis of the polymorphic nature of Balzac's character: who, far from being just a novelist, was in fact a journalist, an entrepreneur and a politician;

2) mechanisms for financing Balzac's works and life: advances, copyright and the active support of a number of leading female figures;

3) Balzac entrepreneur: the printing house; the mines in Sardinia; the activity of art collector;

4) Balzac interpreted via the avenues of Business Economics: the role of the "system" in his life and in his novels.

With reference to the point 1), the attraction towards business is one of the key human features of Balzac and it places himself, as anticipated, as an intriguing "object" for the studies in business and management, as well.

With the suggestions of Zweig (1920) it has to be always kept in mind that Balzac "whenever he heard of a stroke of business to be done he never rejected a business opportunity on the score of literary pride", always pondering (always for the wrong, unluckily) pros and cons of a new adventure.

Put in these terms, if the opportunity had offered, "Balzac might equally well have become a businessman or a slave-dealer, a speculator in real estate or a banker" (Zweig, 1920).

Truly interesting, with reference to point 2), are the sources of Balzac's financial capability during the years.

First of all, it is notorious that whenever "Balzac reached the end of his resources and did not know which way to turn it, it was invariably a woman who came to his help" (Zweig, 1920).

From the early beginning of his appearance on the scene, Balzac in fact strictly adhered to the adagio: "une femme et une fortune".

In this sense, it comes to life the ruthless maxim of some of his fictitious heroes (for instance: Vautrin, the Faustian character of some of his greatest novels): "acquire power, then people will pay heed to you"; according to Balzac, the main issue has always been to acquire power, no matter what kind of, through wealth, political connections, literature, military triumphs and, as such, women.

Far from being a misogynous type, Balzac pays his tribute to the importance, intelligence and vision of female gender, well before the feminist results and movements of the succeeding century.

That said, also the issue of advances has always been, in effect, of certain interest in his battling and enormous life: consider, for instance, that Balzac systematically used to sell the rights (and receive advances) of novels yet to be written.

In doing so, he would push his literary accomplishments under an increasing stress: and it is still hard to be conceived how he mastered to produce such a number of powerful and striking books within this haunting burden pressing on his shoulders.

With regard to his business competencies, even if we have to admit that he run a great deal of enterprises and he often managed to see well ahead of time, Balzac completely lacked some pivotal elements of a wise entrepreneur: he never delegated anything, for instance, since "in business nothing must be left to others" (Zweig, 1920) and he always disdained to keep in good terms suppliers, clients and competitors, missing any preliminary notion of marketing or commercial spirits (Zweig, 1920).

Regarding point 3) and 4): with a vibrant, giant and beautifully articulated world created by his own imagination, his literary world represents presumably the most well articulated and powerful literary system in history.

As the life-cycle systems of the enterprises, in fact, his world has been developed on the basis of some key and fundamental elements, it is open to the environment and it is, most of all, "social", since it depicts facts, processes, social relationships and businesses.

\section{Literature Review and Methodology}

This paper has been developed under the literature of accounting history research.

As widely known, interdisciplinarity has enhanced the growth of accounting history research; this is particularly accentuated by the growing call for studying accounting as a social practice. Within accounting history research, new research topics, research approaches, and the use of different theoretical perspectives and methodological 
approaches drawn from other disciplines, have increased the potentialities and dimensions of the investigations undertaken (Baskerville, 2017).

At the same time, some Authors have recently assessed the role, the scope and the scale of biography in accounting history, pointing out as well the (doubtless idiosyncratic) lessons learned, the methodologies employed, the related ethical requirements and challenges (Burrows, 2018).

In this sense, biographies constitute a rather neglected area of research, as well as religion and education, as mentioned in Spraakman et alii (2018) who analyze and categorize published research papers in three specialist accounting history journals-Accounting History, The Accounting Historians Journal, and Accounting History Review.

As widely known (Carnegie and Napier, 2017) historians, and especially accounting historians, are taught to conduct historical research by using primary source materials (Fleischman and Tyson 2003).

In this sense, Carnegie and Napier (1996) claim that "historical research in accounting gains its strength from its firm basis in the archive". Along this line, archival researchers must confront methodological concerns that include distinguishing fact from opinion.

For the development of that paper, I have made extensively use of the two main bibliographies up to date of Balzac (Zweig, 1920; Robb, 1994) as well as of a comprehensive reading and understanding of some of his writings, inside both the whole corpus of the "La Comédie Humaine" and his correspondence.

In effect, it is of certain use to remember that Balzac was a prolific letter-writer: his general correspondence comprises three volumes of 1.200 pages each (Szypula, 2017).

His published letters - which span professional correspondence, letters to creditors, friends and family, love letters and replies to admiring readers - are significant as a primary source of documentation and as a space for literary creation (Szypula, 2017).

Balzac's business correspondence ranges from letters relating to his businesses, his contracts with publishers and the subsequent lawsuits: particularly intriguing are the exchanges with his editors, punctuated by reclamations over unmet deadlines and unfinished manuscripts (Szypula, 2017). These letters appear rather one-sided since the editors (for instance, Souverain) chase novels and they do not receive reply by Balzac. At the same time, financial constraints and concerns have been so relevant in his daily life that even in the lead up of his marriage to Eveline Hanska his letters are filled with "business", from constant deadlines to hard-pressed finance.

\section{Analysis}

\subsection{Balzac: Coming of Age of a Genius}

Balzac was born in Tours in 1799 and died in Paris in 1850.

At age ten he was sent to the Oratorian grammar school in Vendôme, where he studied for seven years.

In 1814 the Balzac family moved to Paris, and Honore was sent to private tutors and schools for the next two and a half years. In 1816 Balzac entered the Sorbonne. Once his studies were completed, Balzac was persuaded by his father to follow him into the Law; for three years he trained and worked at the office of Victor Passez, a family friend. During this time Balzac began to understand the vagaries of human nature.

In 1819 Passez offered to make Balzac his successor, but his apprentice relinquished to law, announcing his intention to become a writer. The loss of this opportunity caused serious discord in the Balzac household, although Honoré was not turned away entirely.

In 1820 Balzac completed the five-act verse tragedy Cromwell. In 1821 Balzac met the enterprising Auguste Le Poitevin, who convinced the author to write short stories, which Le Poitevin would then sell to publishers. Balzac quickly turned to longer works, and by 1826 he had written nine novels, all published under pseudonyms (in particular: Lord R'hoone, an anagram of Honoré; Zweig, 1920) and often produced in collaboration with other writers.

These books were potboiler novels, designed to sell quickly and titillate audiences; in effect, according to Zweig (1920), "there was a demand for novels, for exciting, melodramatic, romantic, exotic novels".

During that time, Balzac as a journalist wrote essays on various topics including politics which garnered much of his attention, rather than opera and dramas.

Of particular interest for offering a picture inside his real character (that is: a man of gigantic and absolute personality) was the adventure of the "La Revue Parisienne", journal which Balzac owned for some months: 
with the words of Zweig (1920) "nothing must be left to others. He took upon himself the work of five men, not only combining the functions of editor and editorial staff, but even looking at the financial side. He read the proofs, negotiated with the printers, spurred on compositors, supervised the distribution".

The same ambitions, desires, and opinions on his life as a writer and a journalist can be traced all through his supposed political career, as well. The wish to enter political life, which haunted him always, in effect was already beginning to stir in 1819 , when he wrote at the time of the elections to a friend, M. Theodore Dablin, that he dreamt of nothing but him and the deputies. Later on, that was realized to be no more than one of his not numerable flying dreams.

After writing several novels, in 1832 Balzac conceived the idea for an enormous series of books that would paint a panoramic portrait of "all aspects of society". Although he originally called it "Etudes des Mœurs" (literally 'Studies of manners') it eventually became known as La Comédie Humaine, and he included in it all the fiction that he had published in his lifetime under his own name.

All these events are accompanied, and moved along with, by systematic and systematically failing entrepreneurial activities, which will be depicted below.

As such: Balzac the genius, from 1832 on; in fact, whereas a composite and polymorphic nature meets arts and business, life (life in all: that is, living, love, furniture, money, business successes and business failures) tracks art and viceversa.

In her amazing work on Balzac, Elizabeth Gerwin (2017) writes that "he was himself an exemplum of this creative vitality: and if he sought to analyze like a doctor, create taxonomies like a scientist and contextualize events like an historian, above all he wrote with the ingenious and passionate eye of the novelist".

And again, with the words of Lyndon Orr (1912), "in Balzac there was a money-broker, an archeologist, an architect, an upholsterer, a tailor, an old- clothes dealer, a journeyman apprentice, a physician, and a notary".

The tremendous relevance of Balzac in the field of literature is beyond any doubt: yet, the events of his life need to be recalled as well, since Balzac has embraced and swirled facts and events in his life far more than any other author.

\subsection{Financing Balzac}

Preliminary, it might be of certain use, in order to catch better the absolute and relative costs of things, summarize as follows: 15 francs is the copy of first edition of "Le Père Goriot"; 50 francs, the dinner for one in an expensive restaurant; 100 francs, one pair trousers from good tailor; 5.000 francs, the salary of chief clerk in Government office; 52.000 francs, the purchase price of large, three store hose in middle class area (Robb, 1994).

According to Robb, 1 franc at the age of Balzac equals 3 francs of modern times (1994).

The letters of Balzac, when it comes to his financing, depict "an obsessive gambler" (Robb, 1994): "six months hard work and I will be fee " (August 1834);"realistically I need just one more year to pay off my debts" (December 1834); "at last I can see blue skies. Another five months and I shall be solvent" (October 1835); "if I have not found a solution a year from now, I might as well throw in the sponge" (June 1836) and so forth.

To be fair, Balzac "the obsessive gambler", when put on despair, managed to inflate some minor crimes as well, as simulating sales, promissory notes signed by friends who owed him nothing, loans secured under other names and a false depiction of poverty to deceit the creditors (Robb, 1994).

In effect, as M. De Vries correctly pointed out (2007), Balzac himself is famous for his quotation: "behind every great fortune lies a great crime".

\subsubsection{Payments, Advances and Royalties}

Balzac was generally paid in advance, so that his money was safe; and though he could be trusted to finish sooner or later what he had undertaken, he showed a stern indifference to the exigencies of publication month by month. Moreover he would sometimes, in his haste for money, accept new engagements when he already had a plethora of work in hand (Sandars, 1904).

That financial procedure, usually undertaken by Balzac, was an impressive mixture of excessive financial requirements, enormous expenditure of working hours, implacable firmness in demanding the respect for his own rights as the writer and a naive attitude towards those rights of others: all, of course, combined with his usual individualism and with his difficulty in being supported even by his fellow writers, who in general lacked towards Balzac of any spirit of fraternal comradeship. 
Therefore, it is not difficult to believe that Balzac's relations with his publishers (in particular Pichot and Buloz) were particularly stormy, characterized certainly by the author's systematic delays and, in some cases, by the replacement of one work with another but, on the other side, by publishers who launched incomplete works onto the market and reduced advance payments as well.

Some lawsuits were won, some others lost: in all of them Balzac fought alone, as always, eventually exhausted by these disturbing controversies.

To add chaos to chaos, some editors went bankrupt (Werdet in 1837) and the bills of exchange drawn by Balzac were repudiated by his creditors, so that he had to honor 13.000 francs of notes (Robb, 1994).

Another interesting topic, which later became central in the relationship between art and its financing mechanisms, was the protection and protection of copyright, which Balzac was among the first to raise and about which he brought many lawsuits.

In effect, every successful book in France was pirated in Belgium and "the Belgian publishers, who never offered him a sou out of their profits, flooded every country in Europe with editions which they could sell more cheaply than the authorized since there were no author's fees to pay [..." (Zweig, 1920).

He understood the need for a general legal protection on behalf of all artists, but the lack of a common strategic vision (and probably the envy of many against his genius) allowed him to go little further than a modest expectations.

In terms of legal rights on his novels, it has also to be said that Balzac, who showed in that peculiar situation a great deal of circumspection, managed in any case to keep untapped, until at least 1842 , the issue of the collected edition of his work.

Eager to demonstrate to his future wife his wealth, only on the $14^{\text {th }}$ of April, 1842, Balzac sealed in fact an agreement with the publishing firms of Dubochet, Furne and Hetzel, who were granted "the right to prepare at their discretion and for such time of publication as shall appear to them suitable two or three editions of the works published by him up to the present time, or which may be published during the validity of the present contract".

In exchange of the sale of the rights above his entire opera, Balzac received fifteen thousand francs as advance payment plus a royalty of fifty centimes per volume after the sale of forty thousand copies.

Apparently, it was a positive result for Balzac since he managed to obtain a permanent inflows, bound to increase year after year for the mechanism of royalties.

Balzac only had to bear the cost of proof corrections exceeding five francs a folio: amount which was largely overcome in the years, considering the mania of the author for polishing and refreshing his text.

Before the agreement with Dubochet, Furne and Hetzel, in effect, all the biographies of Balzac unanimously confirm that much of the income from his books was swallowed up by the cost of these unending proof corrections.

\subsubsection{Supporting Female Figures}

The numerous female figures that populate Balzac's life respond to two opposing demands: on the one hand, he was devoted to realize his astounding masterpiece and, for doing so, he had to find the wife and the fortune he had for so long been the object of his search; on the other hand, the sensual and impetuous character of the artist and his vital passions made him at the same time an ideal source for romantic love excursions or intellectual friendships.

In this sense, Madame de Berny is a leading female figure in the life of Balzac and the first, after his mother, who economically supported him when Balzac acted as a published and printer (1824; see point 4.3. for further details).

If, according to Szypula (2017), Balzac managed in his correspondence to sublimate the writing of letters in a truly original style of literature, then when Balzac wrote that "(Madame de Berny) kept my head above water by her encouragement and acts of sacrifice" the reader is advised to go inside the lines and to understand her decisive financial support on behalf of the artist.

Maybe less significant in terms of an explicit financial help but, at the same time, probably more relevant for his development as a writer was Zelma Carraud.

Their correspondence started in 1829 and lasted until the death of Balzac in 1850: browsing amongst their letters, full of a deep and devoted mutual friendship, it emerges clear the reasons why Zweig (1920) considered the 
meeting with Zulma a real "piece of good fortune" for Balzac. Pressed by editors, creditors, readers and work, in fact, only in her house he managed to "find solace without being subjected to rapturous admiration on put on show" (Zweig, 1920).

Not surprisingly, with her vivid knowledge of real life, Zulma managed inter alia to make Balzac reduce the fortune of Felix Grandet, key character in the novel "Eugénie Grandet", from 21 million francs to 11 million (later by, Balzac regained to 19 million), demonstrating to the author that the original amount was "not realistic".

A stormy relationship moved Balzac and Madame de Castries (from 1831 on); they were flirting for some months, Balzac appealed by the words of the Madame and the Madame flattered by the letters of Balzac.

Madame de Castries had a renowned salon, the "flower" of the Faubourg Saint-Germain; after a temporary harsh separation, she again received the author of La Comédie humaine, who was able to read her texts there, but she remained perfidious, particularly in her allusions to the late Madame de Hanska.

Again in 1831, that Madame de Hanska precisely, motivated partly by boredom and partly by a desire to influence the life of a great writer, wrote for her first time to Balzac.

After the entire 1832 spent on a hard pull and spring, Balzac and Madame de Hanska met at last in September 1833: Balzac crossed into Switzerland, Neuchâtel, and he sent word to Hanska that he would visit the garden of the Maison Andrié, where she and her family were staying.

According to some authors (Zweig, 1920) they met later that day (September 25) at a spot overlooking Lake Neuchâtel; he noticed a woman reading one of his books and "he was overwhelmed with her beauty".

Madame de Hanska constituted for Balzac the last of a long queue of illusions, in which he spent the remaining of his life and in which he was to die: in 1850 he and Madame de Hanska married and, because her, he restored and renewed Rue Fortunee, deploying as such an enormous weight of money.

Furthermore, Madame de Hanska played certainly a role in shaping the directions of his work from 1831 on; and certainly, even if seized and haunted by her majestic beauty, Balzac considered in 1842 - when Monsieur de Hanski was dead - that Madame was a widow and succeeded in the heritage of the deceased husband.

Once again: "une femme et une fortune": with a touch of sarcasm, in effect, Zweig (1920) notes that when he reached Madame de Hanska in 1843, St. Petersburg, "his first steps were towards the Kutaisov house [..] there was symbolic significance in the fact that it was situated in a street called Grande Millione".

Balzac, in that situation, was probably wandering to become an opulent donee.

Another truly decisive female figure in Balzac's life is, in the end, the Countess Guidoboni Visconti, known by Balzac in 1836, at the height of the sentimental storm with Madame de Hanska.

Although she lacked, unlike the latter, a literary talent capable of guiding Balzac's artistic choices, the Countess in fact played a central role in the author's human and artistic survival.

First, Balzac knew her at the peak of his impressive debts (over 151.000 francs, which equals according to Robb 3 times of modern francs; Zweig, 1920 and Robb, 1994) and the Countess, discreetly and carefully, helped him to manage and then to overcome temporarily his financial difficulties.

Secondly, the Countess helped Balzac proactively, so that she did not appear to act under a mere act of mercy: according to Zweig (1920), "Count Guidoboni-Visconti had inherited from his mother a sum of money which he had difficulty in collecting and since he possessed no aptitude for dealing with affairs of business he had practically given up hope of recovering the amounts. The Countess suggested that Balzac [... of whose energy and business instinct he was well aware, should be authorized to go to Italy as his agent".

The step above is such important since Balzac was made responsible for acting as a truly and purely homo economicus; moreover, the Countess had the good intuition of his best entrepreneurial qualities (energy and instinct), better probably than Balzac himself who, relying only on these latter two, when he had to devote himself to his activity of entrepreneur always failed, lacking the time, the attention and the ability to team up with the environment (clients, suppliers, employees, competitors and so forth), all of which are critical sources of fair entrepreneurship.

The engagement was repeated, again with success, the year later (1837): in doing so, Zweig (1920) commented that Balzac "was an excellent businessman so long as it was not his own affairs with which he was concerned". 


\subsection{Balzac Entrepreneur}

A convincing portrait of Balzac's multifaceted genius and of his propensity towards financial adventures and speculations is offered by Zweig (1920), who states the "he had been offered the choice between becoming a Rothschild or the creator of the Comédie humaine, it is very doubtful whether he would not have elected to be a leading light in the world of finance rather than in the world of letters".

With the same tone, Robb (1994) notes that "as usual, Balzac looked to literature for an answer to his problems"; and Balzac himself wrote in a letter to Madame de Hanska (1843) that "if, for the last ten years, I had been in the grocery business I would now been a millionaire".

Even if moved by an explicit genius, also from the point of view of entrepreneurial creativity, and even if guided by the desire to pave his way, whatever the means and instruments to do so, it is however necessary to declare immediately that Balzac lacked every capacity of coordination and delegation, which are a contrario mandatory virtues of the good entrepreneur.

In effect, he conducted all business matters without any help whatsoever, arranging his contracts and managing lawsuits without a business agent or a professional adviser.

That said, below are presented three pivotal experiences of Balzac as an entrepreneur.

\subsubsection{Publisher and Printer}

An impressive biography of Balzac, which has been arguably one of the source of the magnificent work of Zweig, was released in 1904 by M.F. Sandars, who browsed extensively his correspondence and who depicted his experience as a publisher and a printer in the following terms.

In 1824 Balzac decided to become first publisher and then printer. In doing so, he started his publishing campaign with the idea of bringing out compact editions of the complete works of different authors in one volume, and began with Moliere and La Fontaine, carrying on the two publications at the same time, for fear of competition if his secret should be discovered.

Balzac was not able to obtain support from the trade, and had not sufficient capital for advertising. Therefore by the end of the year not twenty copies were sold, and he lost 15.000 francs on this affair alone. Consequently, in order to save the rent of the warehouse in which the books were stored, he was obliged to part with all the precious compact editions for the price by the weight of the paper on which they were printed.

At that time, Balzac owed about 70.000 francs; but his creditor, M. d'Assonvillez, instead of filing him for .bankruptcy, introduced Balzac to a relation who was making a large fortune by his printing-press.

Then, Balzac's father was persuaded to provide the necessary funds, and handed him over 30.000 francs with which to start the enterprise. In August, 1826, Balzac began again, first by himself and afterwards with a partner named Barbier, whom he had noticed as foreman in one of the printing offices to which he had taken his novels. Considering that a printing license cost 15.000 francs in the time of Charles $\mathrm{X}$, that when this had been paid, Barbier had received a bonus of 12.000 francs and that 15.000 francs had been spent on the necessary materials, there remained very little capital with which to meet the current expenses of the undertaking.

Nevertheless, the partners started, having bought from Laurent for 30.000 francs the premises at No. 7, Rue des Marais Saint-Germain, now the Rue Visconti.

"Here he battled with others; and since, except on paper, he never possessed business capacity, he failed and went under; but by his defeat he paved the way to future triumph. He passed through an experience possibly unique in the career of a man of letters, one which imparts the peculiar flavor of business, money, and affairs to his books, and which fixed on him for all his days the impression of restless, passionate, thronging humanity which he pictures in his books" (M.F. Sandars, 1904).

When, towards the end of 1827 , an opportunity occurred of becoming possessed of a type-foundry, the partners did not hesitate to avail themselves of it. This new acquisition only appeared likely to precipitate the catastrophe, and Barbier prepared to leave the venture.

At this juncture Madame de Berny came forward with substantial help, and allowed her name to appear as partner in his place. However, even this assistance did not long avert disaster (bankruptcy was impending), Madame de Berny and his sister Laure implored Madame de Balzac to prevent this. The latter begged a cousin, M. Sedillot, to come forward, and at least to save the honor of the family. M. Sedillot in fact set gallantly to work to disentangle the affair, and to free Balzac from its meshes. As a result of his efforts, the printing-press was sold to M. Laurent, and the type-foundry became the property of the De Bernys, under whom it was successful. 
The activity of printer, in addition to marking the character of Balzac and to make him able to better investigate the strongest passions that govern the soul, draws a man as well who, always with the fair spark for business, is systematically not able to bring any of it to completion. Proof of this is the great success that, with hands different from those of Balzac, will arrive to M. Laurent.

From an economic and psychological point of view, in effect, Balzac shows all the traits of the animal spirits of the brilliant entrepreneur, able to identify new areas of profit and new entrepreneurial spaces, but he lacks all the dimensions of a fair manager and director: he always being disorganized, centralized, pressed by financial urgencies, unable to choose people, time and location.

Only consider that "in his anxiety to net the maximum profit Balzac fixed the price per volume at twenty francs; this frightened the booksellers; the first thousand copies, instead of being the harbingers of innumerable [..] remained in the printer's stockroom unwanted" (Zweig, 1920).

And furthermore: "(all the undertakings of Balzac) began to pay their way as soon as Balzac vanished from the scene and they could be carried on with the sober and patient judgment which a commercial enterprise demands" (Zweig, 1920).

With the words of Zeef (1951), who offers an intriguing picture of the case, "the true answer seems to be that Balzac was not a business man at all. Although he was responsible for the bookkeeping, many transactions were not recorded and Balzac had to resort to his memory, which often differed from that of his creditors".

The role (salvific or limiting) of his family and the constant financial support of some great female figures are typical themes of Balzac's life.

In this sense, as anticipated, Madame de Berny appears on the stage as the first leading female figure who, for the sake and love of "this ardent young man" (Zweig, 1920), helped him in his frantic daily life.

The business of publishing and printing, although unsuccessful, was nevertheless a brilliant source for literature and novels.

In fact, one of Balzac's most celebrated work, Lost illusions (1843), which incidentally carves a strongly negative depiction of journalism (the main character is "sucked in the murky world of journalism, corrupted and finally spat out again", Robb, 1994), also takes an impressive resemblance with the past of Balzac as a printer: only consider the character of Dauriat, who declares that "I don't risk two thousand francs just to get two thousand francs back": life of Balzac, in terms of both his unsuccessful activity as journalist and his failure as a printer, precedes and shapes his art.

\subsubsection{Voyage en Sardinia}

Pressed by "gazettieri" and creditors, in March 1838 Balzac embarked from Marseille with a route to Sardinia, apparently the new Eldorado, where he longed to crown his yearnings for economic prosperity through the exploitation of deposits of waste abandoned on the island.

Below are the facts, as are they depicted directly by the Author in his "Voyage en Sardinia" (a collection of letters, 1838-1840, from the Author to Madame de Hanska, which are included in the general correspondence between them).

In March, 1837, Balzac paid a visit to Italy: travelling through a part of Switzerland, stopping at Milan, Venice, Genoa, and Florence, and returning to Paris on May 3rd. If one object of Balzac's journey was to visit Florence to see Bartolini's bust of Madame de Hanska, it was in Genoa when he met a wily merchant, to whom he unfortunately confided the last scheme for making his fortune.

He had read in Tacitus that the Romans found silver in Sardinia; and it occurred to him that, as the ancients were not learned in extracting metals, silver might still be found among the lead which was turned out of the mines as refuse. The Genoese merchant appeared much interested in Balzac's conversation, and remarked that, owing to the carelessness of the Sardinians, whole mountains of dross, containing lead, and most probably silver, were left in the vicinity of the mines. He was most obliging: he promised to send Balzac a specimen of the dross that it might be submitted to Parisian experts, and if the result were satisfactory, Balzac and he were to ask for a permit from the Government at Turin, and would work the mines together.

When this had been arranged Balzac departed in high spirits, determined to keep his secret carefully, and feeling that at last he was on the high road to fortune. 
In March, 1838, before he settled in his new abode, he started on a journey to Sardinia to investigate matters himself about the mines. It was a year since the Genoese merchant had promised to send him a specimen of the dross, and as nothing had yet arrived, he was beginning to feel anxious.

His five days' journey to Sardinia was most uncomfortable, as he travelled in a rowing-boat belonging to French coral fishers. The food caught consisted of execrable soup, made from the fish caught by the fisher men during the voyage; and Balzac had to sleep on the bridge, where he was devoured by insects. To add to his misfortunes, the boat was kept for five days in quarantine in view of the port, and the inhabitants refused to give the occupants any food, or to allow them in a bad storm to attach their cables to the port-rings.

No doubt he was not disposed to take a particularly favorable view of Sardinia, as it was to him the scene of a bitter disappointment. He had been right in his calculations about the value of the refuse from the mines: the dross contained 10 per cent of lead, and the lead 10 per cent of silver. But a Marseilles company as well as his Genoese friend had been beforehand with him, they had obtained from the Government at Turin the right to work the mines and were already in possession. Balzac's monetary sacrifices, and the hardships he had suffered on his journey, were in vain.

The affair shows the typical traits of all of Balzac's enterprises: ingenious at the start but, as always, improvident, late in time and unrealistic in its ways.

If the long delay for the start of the expedition can be justified by the usual dire straits of the writer, in fact, his trust in the Italian merchant identifies in Balzac a profound dichotomy between the artist (capable, better than anyone else, of painting the splendors and miseries, weaknesses and lights of the new bourgeoisie) and the human being, often dazzled by hypothetical flashes of financial glory and unable to grasp the dark venues of the individuals he approached from time to time.

\subsubsection{Balzac the Art Collector}

From 1846 to 1850 Balzac extensively worked on his forthcoming marriage with Madame de Hanska; once again, the pivotal biography of M.F. Sandars (1904) comes to help.

Since 1846, in particular, Balzac went under the spell of the "art collector": in 1846, after a journey to Italy, several pictures were to follow him from Italy: a Sebastian del Piombo, a Bronzino, and a Mirevelt, which he describes as of extreme beauty; and with his usual happy faith in his own good luck, he hoped to pick up some other bargains such as "Hobbemas and Holbeins for a few crowns," in the towns through which he would pass on his journey.

Since the uncomfortable issue was, using Zweig (1920), "to amass a valuable collection of works of art without an adequate supply of capital", Balzac with his resourceful spirits started to buy, collect and sell furniture as he was, in effect, an expert in the field: he still bought in the second hand shops and then happened to announce his discovery of an old master of a piece of ancient craftsmanship.

With the words of Robb (1994) "Balzac acquired a chest of drawers and a writing desk which the dealer assured him had belonged to Marie de Medici and Henri IV; he persuaded Leon Gozlan to publish an article on the two pieces in the Musée des Familles so that he could sell them for 3000 francs".

Both Zweig (1920) and Robb (1994) find in the correspondence of Balzac further elements of this new line of business: in a letter, his former mentor Auguste Le Poitevin complains that Balzac "no longer wishes to be a novelist full of skill [..] he has decided to become a furniture salesman"; in another piece of paper, Madame de Hanska mourns about the astounding expenses of 100.000 francs recorded, for furniture and ornaments, in only three years from 1846 to 1848 .

That said, there began to appear from 1846 in Balzac's letters exact descriptions of the Sevres china, the inlaid furniture, and the bric-a-brac to adorn their future home together. As usual, on his return he found his affairs in utter confusion, was pursued by creditors, and was absolutely without money.

Nevertheless, Balzac was very happy superintending the building operations in Rue Fortunee (now Rue Balzac), deciding exactly where his different treasures would look best in his new abode, and hunting for fresh acquisitions to make every detail perfect. Later on, his letters from Russia to his mother when she was taking charge of the house show how dearly he loved all his household goods, and how well he was acquainted with their peculiarities.

In 1846 and 1847, his letters confirm the instinct and the passion of the confirmed collector, who has no thought beyond his bric-a-brac. His excitement is intense because Madame de Hanska has discovered that a tea service in 
his possession is real Watteau, and because he has had the "incredible good fortune" to find a milk jug and a sugar basin to match it exactly.

A detailed inventory of the house in Rue Fortunee is included in the correspondence of Balzac and covers 47 pages of a detailed list: amongst the goods, 10 clocks, 12 candelabra, 36 vases, 1500 francs of mirrors, 3000 kilograms of gilded bronze, a salon in gold, a gallery with 26 supposed old masters.

Always stripped between his fairytale and the brutal reality of money, Balzac writs that, for meeting all his financial needs, he will have to "concoct some gargantuan novels and successful plays and eat crusts of bread smeared with garlic like the Jews" (Robb, 1994).

The remainder is notorious: Balzac and Madame de Hanska married only in 1850, house ready to be lived in, a few months before the death of the author.

From that moment on, Madame de Hanska lived in France; the house, built before the revolution, which was agreed a price of 50.000 francs (paid eventually by the widow in 1850), was resold thirty-two years later for 500.000 francs (furniture included) to one of the Rothschilds, even if Madame de Hanska was allowed to live there until her death.

This phase of Balzac's life is characterized by a constant financial imbalance, tense as it is between outflows (house plus furniture) well higher than the inflows. As usual, Balzac's highly centralizing nature and his impetuous character exacerbate the difficulties: furniture of little value are added to valuable goods, as the passion for collecting (being the Comédie itself a wonderful collection) is combined with disdained management of the daily life; above all, the grandeur is not aligned with his financial availability.

That passion for collecting arts and, in general, for having sensational and bizarre habits, is a constant trait of Balzac's personality: already in his youth, in fact, "he rented the second floor of the house in rue Cassini, bought opulent furniture and no dandy was able to say that his clothes were richer and more expensive than those of Balzac" (Zweig, 1920).

At the same time, life, works and science itself are somehow a matter of collecting and make relationships between the parties (see later the notion of System): science in particular, as Robb (1994) remarks, is "a glorified form of cataloguing".

In his late masterpiece Cousin Pons (1847), Balzac crafts the character of Pons, a small-time musician, who a serial and manic big-time collector of objets d'art; because he is devoted to and jealous of his collection, he lives in poverty: once again, as in the case of the activity of printer, life inspires literature and vice versa.

Incidentally, Pons art collection has been studied as a "repository of chance" and as a "proto statistical object" by Bell (1994), who concludes his paper with the words "this final great novel foregrounds once again the conflict in Balzac's work between causal reasoning and aleatory circumstances".

\subsection{The System in Balzac Life and in His Work: Back and Forth}

As said, Balzac is, amongst all, a collector: of novels, financial failures, characters, furniture, inspiring madams, grandeur and irritating editors.

And in his stunning universe of different collections, Balzac always works for an order and for a system: a central key necessary to envelop first and disentangle later his cosmos.

"La Comédie Humaine" is a system (made up of 593 recurring characters, see Robb, 1994) and, as such, the Sun of the System - put in the straight center of the System itself - is money.

For Sumberg (2000), "every age has its Kabbalah and that of today is of institutional money flows. Financial, business, accounting matters fill some of Balzac's pages in almost wearisome detail".

Undoubtedly, central in the life and, consequently, in the work of Balzac is the quest and the love for money: put in these terms, the love of money is the root of life in society (Pasco, 2017) and money is dominant in the whole "La Comédie Humaine" as it was in the life itself of Balzac: according to Zweig (1920), "always the more he earned, the more he wanted to earn".

In effect, the life of Balzac (tumultuous in terms of both industrial and commercial efforts, as seen above, and literary results) is strictly intertwined with the fictional life of some of his major characters.

Consider for instance when Blondet, Finot, Couture and Bixiou (in La Maison Nucingen, 1838) settle back to discuss "the omnipotence, the omniscience, the omniexpediency of money". 
Money is the main instrument for assessing the "true" (fair?) value of tangible assets, like land, gold, precious stones and paintings: land itself, in fact, "continued to have importance in many of the functions that it served before the revolution, such as in justifying a title or in gaining a position of importance" (Pasco, 2017) but at the same time "it was rapidly becoming little more than one component of capital" (Pasco, 2017) and a factor of exchange or value.

According to the magmatic composition of capital, in the ideal balance sheet of Balzac, a person is easily to be measured in monetary terms, as well: for instance (in Gobseck, 1830) Maxime de Trailles impudently tells Gobseck "I defy you to find a more handsome capital than in this one on Paris" referring to a young lady.

The vital drive in Balzac is capital, whether human, tangible or intangible, and as such capital offers the impulsion for the most important movements of Balzac's society (Pasco, 2017).

Once again in Balzac, money is power and power relies in money: Gobseck states it in clear terms when he reflects on money and says that "is not life a machine whose movement is impelled by money" (Gobseck, 1830).

Well aware of the differences between the notional/ideal value of money and its implicit/real value, Balzac also covers in his work the discrepancy between fiat money and "assignats", and in doing so the role of inflation (Levasseur, 1894).

Both G. Lukács (in his "Realism in the balance", 1938) and A. Wurmser (in his “"La Comédie inhumaine”, 1965) again pose the role of money and the driving forces of capitalism as the core of Balzac work: according to the first, Balzac was strongly aware of the rapidly growing forces of capitalism whilst for the second "Balzac's novels would not take place if the questions of money were not posed".

In fact, according to R. Barthes ("Le Degré zero de l'ecriture", 1953) "Balzac was writing at the precise moment when a new economic structure is joined onto an older one, thereby bringing about decisive changes in mentality and consciousness".

With rare exceptions, not even love could prevail against money (Pasco, 2017): and when Balzac writes to Madame de Hanska he told her, so she would have an exact measure of his love, that each page devoted to her represents 60 francs of lost income (Robb, 1994).

In this sense, Eugénie Grandet, 1833, is the main masterpiece, in the work of Balzac, which most clearly demonstrates that assertion (love does not predominate money) as well.

The plot of the novel is below summarized in short, in order to refresh its main topics.

Eugénie's father Felix is a former cooper who has become wealthy through both business ventures and inheritance. Some parties (his banker and his lawyer) are eyeing the inheritance from Felix and, in this sense, they constantly visit the Grandets to get Felix's favour. On Eugénie's birthday, in 1819, Felix's nephew Charles Grandet arrives from Paris unexpectedly at their home having been sent there by his father Guillaume. Felix considers Charles to be a burden and plans to send him off overseas to make his own fortune. However, Eugénie and Charles fall in love with each other, and hope to eventually marry. She gives him some of her own money to help with his trading ventures and, for that hazard, Felix is angered with her: this leads to his wife's falling ill with grief, and his daughter's being confined to her room. Eventually they are reconciled, and Felix reluctantly agrees that Eugénie can marry Charles. Yet, when in 1827 Charles returns to France, he is no longer in love with Eugénie; he has become very wealthy through his trading, but he has also become extremely corrupt. He becomes engaged to the daughter of an impoverished aristocratic family, in order to make himself respectable and he writes to Eugénie to announce his marriage plans and to break off their engagement. At the end of the novel, after some other misadventures (a marriage with a sudden death of the husband), although by the standards of the time she should be unhappy - childless and widowed - Eugénie is instead quite content with her lot.

From the brief summary above, it is clear how the novel wonderfully intercepts some of the issues that have been discussed so far:

1) the frustrated desire of a young girl to place first love to all: Eugénie gift to Charles of a sum of money (all in gold coins!);

2) the archetype of greed and the desire to systematically increase one's social position, in the character of Felix: who, "acutely cognizant of the worth of things and of those aspects of his society that will allow him to increase his hoard" (Pasco, 2017), fails to recognize the value of the relationships that depend on family, love and trust;

3) the key role of "inheritance" in the creation and maintenance of an economic fortune; in "La Comédie Humaine", in effect, most often funds come from an inheritance rather than legitimate earnings and profits and 
Eugénie Grandet is the first of the four Balzac's novels called "inheritance novels" (Eugénie Grandet, Ursule Mirouët, La Rabouilleuse and Le Cousin Pons);

4) the mixed opinion of Balzac regarding debts: in fact, if a declared bankruptcy dishonors the honest, "debt do not dishonor anyone when they are in the open" (Les Faiseur, 1839);

5) Balzac's severe final judgment of the bourgeois class, so that Eugénie has learned to live life on her own terms, and has learned of the hypocrisy and shallowness of the bourgeois.

Another topic which is masterfully developed both in that book and, later, in Cesar Birotteau, is the relationship between money, entrepreneurship and bankruptcy, an issue largely known by Balzac himself after the conspicuous number of flawed and unsuccessful enterprises he embarked: on the premise above (that bankruptcy is considered not honorable), Felix plans to maneuver his dead brother's debt through Parisian financiers and erase it "without costing either his nephew or himself a penny".

Using some receivership/bills issued by a primary bank, in fact, Felix first make the creditors believe that the inheritance of his brother is solid and wealthy: then, he manages them to tuck the debt away, lured by the inventory of the assets of his brother. As a final "coup de théâtre", when the creditors receive by the banks only $47 \%$ of what is owed and they begin to mourn for the remainder, Felix is able to bundle that remainder in one single account: in fact, "not only it is easier to settle with a group than with individuals" (Pasco, 2017) but also "the total of the final settlement amount seems more generous than the much smaller sums that actually go to the individual creditors" (Pasco, 2017).

The plot above confirms what it has already been written earlier in relation to Balzac's creativity regarding financial incidents: creativity that, enlightened by his artistic genius, has found fertile ground in the author's life. Felix's diabolical ability should not, however, be seen, in this sense, as a title of merit: his miserable death is a straight confirmation of this, such as are the practices (more painful, linear, honest and, at least apparently, appreciated by Balzac) through which another major character in his novels (Cesar Birotteau) manages to repay his debts.

Cesar Birotteau (1837) depicts the life of the title character, a man of peasant origins from the Touraine region. At the start of the novel, in 1819, he owns a successful perfume shop, La Reine des Roses, he has been elected deputy mayor of his arrondissement in Paris and he has been awarded the Legion of Honour. Due to a number of concurring financial speculations (in particular: some property renewals and the launch of a new product from his shop) he runs up large debts. Two evil characters (a misleading notary and a former shop assistant) manipulate to make Cesar ruined, fact that in effect happens: he declares bankruptcy, sell his business to his assistant and retire from business, eventually paying off all of his debts. Cesar dies shortly after, happy that his honour has been restored.

As in Eugénie Grandet, that novel intertwines a masterful plot with financial and economics accidents which are contemporary, current in Balzac's life and eternal: the quest for increasing the capital, the intersection between professionals and banks, the leverage of debts.

In these terms, Cesar Birotteau is a truly leading character in the universe of the Comédie, since he is both a victim (of business partners who cheat him, usurers and banks who bleed him) and also personally responsible for his own ruin because, for the first time in his life, he risks more than he can afford to lose: in effect, the dramatic life of the honest and naive (Birotteau) who was caught in a trap of a thousand legal and financial quibbles does not differ much from that in which many of today's small, honest but naive entrepreneurs and savers often find themselves caught in.

Most strikingly, perhaps, is the exploration of the world of high finance through Cesar's visits to the bankers du Tillet, the Kellers, Nucingen and Gigonnet during the second half of the book: those visits depict, only four years after Felix Grandet, an environment towards which Balzac nurtures fascination and scorn at the same time. Moreover, chapter 14 is titled "A General History of Bankruptcy", and here Balzac explains the bankruptcy laws as they existed in his time, and how they were frequently abused by dishonest businessmen who wanted to escape their debts (Felix Grandet, for instance).

In the end, Cesar is shown to be an exception in that he chooses to honor all of his debts: being the final words of the novel "the good priest sped a soul to heaven, where the martyr to commercial integrity should receive an unfading palm".

Placed amongst the two masterpieces, another reflection regarding debt is found in Balzac's tale "Melmoth reconcilie" (1835), in which the bank teller Castanier sinks ever deeper into debt to satisfy his mistress' whims, until, reaching the point of no return, 'he prefers fraud to honest bankruptcy and dips into the bank's till'. 
Castanier (1835) is not evil and pressed by a monolithic desire of money (as Felix Grandet, 1833, is) but he does not possess the will of Cesar Birotteau (1837) to honor his debt: the meditations of Balzac regarding debt were still in process all along time.

$* * *$

As it is widely known, the study of systems is a key variable in Business Economics and, as such, both the life of Balzac and his monumental work perfectly reflect the contents of the system in itself: an open whole, coherent within itself, guided by the driving force of money, the true inspiration of the social behaviors of both Balzac and his characters.

That said, the paradigma of Business Economics also let us glimpse the reasons why Balzac was a disastrous entrepreneur.

Creative, moved by the fury of his genius, animated by feverish spirits, always able to find forms of profit ahead of time, his personality and his genius were also, in fact, the causes of his economic failures: he centralizes, he does not share, he despises his competitors, at times he humiliates his suppliers (in particular the publishers), he trusts those who does not have to and vice versa, he does not plan, he is not calm because of the financial turbulence of his life; economic failures, on such premises, were inevitable.

In fact, as some Authors have pointed out (Gerschenkron, 1978), Balzac himself - and consequently his characters - probably failed to catch the relevance, when doing business, of the time horizon component: "cheating, brazen use of political influence, bribery, theft of inventions, forgeries, and blackmail- all sorts of devices for quick enrichment which either bordered on the criminal or were the very thing- did not require a high time horizon".

\section{Results, Originality and Limitations}

To the best of my knowledge, this paper represents the first analysis of Balzac's life (and therefore of his works) through some pivotal financial moments of his existence.

In this sense, the close connection between life, economy accidents, social choices and art emerges and it hopefully depicts a neglected side of a great writer.

With the superb remarks of Zweig (1920) "by laboring with workmen, battling with usurers and bargaining desperately with wholesale merchants, he had acquired an incommensurable knowledge of social conditions and contrasts" and, in doing so, "when his imagination was fused and interpenetrated with reality, was it possible for the wondrous substance of the Balzac novel to emerge as the most perfect compound of realism and fantasy".

The main limitation of the paper resides in the enormous mass of the production of Balzac: the Comédie humaine and his correspondence, which both are vital in depicting the research question covered in this paper, equal thousands of pages.

As such, there is still a considerable volume of research to be carried out along this avenue.

\section{References}

Balzac, H. (2018). Letters to Madame Hanska: Born Countess Rzewuska, Afterwards Madame Honoré De Balzac, pp. 1833-1846. Classic Reprint, Forgotten Books.

Barthes, R. (1953). Le Degré zero de l'ecriture. Le Seuil, Paris.

Baskerville, R., Carrera N., Gomes, D., Lai, A., \& Parker, L. (2017). Accounting historians engaging with scholars inside and outside accounting: issues, opportunities and obstacles. Accounting History, 22(4), 403-424. https://doi.org/10.1177/1032373217732349

Bell, D. F. (1994). Statistical Thinking in Balzac: "Le Cousin Pons". SubStance, 23(74), Special Issue: Between Science \& Literature, 22-37. https://doi.org/10.2307/3685065

Burrows, G. H. (2018). Biography in accounting history: Some personal reflections, Accounting History.

De Vries, M. K. (2007). Money money money. Organizational Dynamics, 36(3), 231-243. https://doi.org/10.1016/j.orgdyn.2007.04.001

Gerschenkron, A. (1978). Time Horizon in Balzac and Others. Proceedings of the American Philosophical Society, 122(2), 75-91.

Levasseur, E. (1894). The Assignats: A Study in the Finances of the French Revolution. Journal of Political Economy. https://doi.org/10.1086/250201 
Lukács, G. (1938). Realism in the balance. Norton, New York.

Mirbeau, O. (1907). La Mort de Balzac. Bibliothèque Charpentier - Fasquelle, Paris.

Mortimer, A. K. (1997). Balzac's "Ursule Mirouët": Genealogy and Inheritance. The Modern Language Review, 92(4), 851-863. https://doi.org/10.2307/3734205

Orr, L. (1912). Famous Affinities of History. 1st World Library, Fairfield.

Pace-Siegge, M. (2018). How homo economicus is reflected in fiction - A corpus linguistic analysis of 19th and 20th century capitalist societies, Language Sciences, pp. 1-15. https://doi.org/10.1016/j.langsci.2018.07.005

Robb, G. (1994). Balzac: a biography, Picador. W.W. Norton \& Company, New York.

Sandars, M. F. (1904). Honoré de Balzac: his life and writings. Kennikat Press, London.

Spraakman, G. P., \& Quinn, M. (2018, June). Accounting History Research Topics - An Analysis of Leading Journals, 2006-2015. Accounting Historians Journal, 45(1), 101-114. https://doi.org/10.2308/aahj-10567

Sumberg, T. A. (2000). Balzac: our contemporary. Modern Age.

Watts, A., Gerwin, E., Tilby, M., Szypula, E., Bell, D., Pasco, A., ... Jourdan, E. (2017). The Cambridge Companion to Balzac. Cambridge University Press.

Wurmser, E. (1965). La Comédie inhumaine. Gallimard, Paris.

Zeef, C. F. (1951). Balzac as a Business Man. The French Review, 25(2), 96-103.

Zola, E. (1923). The influence of money in literature. Fasquelle, Paris.

Zweig, S. (1920). Balzac. Viking, New York.

\section{Copyrights}

Copyright for this article is retained by the author(s), with first publication rights granted to the journal.

This is an open-access article distributed under the terms and conditions of the Creative Commons Attribution license (http://creativecommons.org/licenses/by/4.0/). 